\title{
HERE, HidDEN, IN MY HEAD (3H) STRATEGY: AN INTERACTIVE SOLUTION TO INCREASE STUDENTS' READING COMPREHENSION
}

\author{
Mike Amelia \\ Universitas Bina Sarana Informatika, Indonesia \\ E-mail:ameliamike@yaboo.co.id
}

\section{Yosi Delfitra}

Universitas Mahaputra Muhammad Yamin, Indonesia

E-mail:delfitravosi@yahoo.co.id

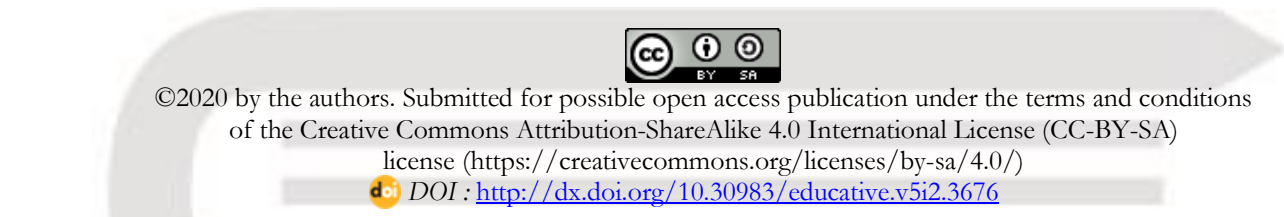

\begin{tabular}{|l|l|l|} 
Submission : November 07, 2020 & Revised : November 22, 2020 & Published : December 31, 2020
\end{tabular}

\begin{abstract}
The eighth-grade students of SMPN 2 Danau Kembar of West Sumatra, Indonesia, had a problem with their reading skills since they unexpectedly did not understand the texts well. The implementation of an inappropriate learning strategy was criticized as one of the factors contributing to the problem. This study aimed to determine the impact of the $3 \mathrm{H}$ strategy on increasing the student's ability to understand the descriptive text. It was quasi-experimental research in which two classes were assigned to experimental and control classes. Each class consisted of 24 pupils (VIII-A) as an experimental class, and 24 pupils (VIII B) as a control class were selected as a sample through an objective inspection. The mean score of understudy reading perception in the test class is 75.71 higher than the mean score of student reading comprehension in the control class is 69.54 . The researcher was given 2,91 for the data $\mathrm{T}$ calculated and 1,68 for the Ttable. Overall, $\mathrm{H} 0$ was rejected, and $\mathrm{Ha}$ was received. In view of the findings of the research, teaching reading through the use of the $3 \mathrm{H}$ strategy has a positive effect on students reading understanding.
\end{abstract}

Keywords: here, hidden and in my head $(3 \mathrm{H})$, reading comprehension

\section{Abstrak}

Permasalahan yang dihadapi oleh siswa kelas delapan SMPN 2 Danau Kembar di Sumatera Barat, Indonesia dalam kemampuan mereka dalam memahami teks merupakan landasan dasar permasalahan dari penelitian ini. Diantaranya ditemukan fakta bahwa kemampuan siswa memahami teks berada dibawah standar yang diharapkan. Ha ini dikarenakan beberapa faktor salah satunya adalab lemabnya strategi yang digunakan pada saat proses pembelajaran. Tujuan penelitian ini adalah untuk megetabui efek dari strategi $3 \mathrm{H}$ (Here, Hidden, and in my Head) dalam memahami teks deskriptif. Metode riset ini adalah quasy experiment. Siswa kelas delapan SMP N 2 Danau Kembar merupakan populasi penelitian ini. Kelas VIIIA (24 orang) sebagai kelas experimen dan kelas VIII B (24 orang) sebagai kelas kontrol merupakan kelas sampel yang dipilih dengan menggunakan teknik purposive sampling. Pada kelas experimen diperoleh rerata 75,71, sementara itu rerata kelas kontrol adalah 69,54. Peneliti juga mendapatkan Tcalculated sebesar 2,91 dan Ttable sebesar 1,68. Dari data yang didapatkan jelaslah bahwa HO ditolak dan Ha diterima. Dengan demikian dapat disimpulkan babwa penggunaan strategi $3 \mathrm{H}$ memberikan efek positif dan dapat meningkatkan kemampuan pemahaman membaca siswa pada teks deskrptif.

Kata kunci: here, hidden and in my head (3H), Pemahaman Membaca

\section{Introduction}

Reading is designed to understand the ideas that the author intends to put forwards to make readers understand the ideas that the author wants to put forwards. Reading is the process of finding and understanding the meaning of the text. It is also intended to look 
at the background of science. The level of a person's reading understanding varies ${ }^{1}$. By reading, the knowledge of a person will increase due to the ideas of others. To be able to read properly, one cannot interpret the information only by word or sentence. $\mathrm{He} / \mathrm{she}$ must understand and read the entire contents of the text so that the meaning is received completely. It cannot be denied that one's reading comprehension is part of the mental representation that the reader has ${ }^{2}$. Reading text must be in line with the point reader mindset, in other words, the same text can be implemented in different ways by different people.

Reading comprehension is the understanding of a text by connecting language processing, such as understanding words, connecting words, and understanding the world ${ }^{345}$. Reading comprehension is a complex language skill and requires the reader to connect to the knowledge behind reading material ${ }^{678}$. A reader must be able to decode words in a good way so that long text can be

1 David Collingwood, 'Understanding and Teaching Reading Comprehension. Handbook', Educational Psychology in Practice, 2015 <https://doi.org/10.1080/02667363.2015.1052233>.

2 Abbas Pourhosein Gilakjani and Narjes Banou Sabouri, 'How Can Student Improve Their Reading ComprehensionSkill?', Journal of Studies in Education, 6.2 (2016), 229 <https://doi.org/10.5296/jse.v6i2.9201>.

${ }^{3}$ Namhee Suk, 'The Effects of Extensive Reading on Reading Comprehension, Reading Rate, and Vocabulary Acquisition', Reading Research Quarterly, 52.1 (2017), 73-89.

4 Stephen Krashen, 'Reading and Vocabulary Acquisition: Supporting Evidence and Some Objections.', Iranian Journal of Language Teaching Research, 1.1 (2013), 27-43.

${ }^{5}$ Barbara A Wasik, Annemarie H Hindman, and Emily K Snell, 'Book Reading and Vocabulary Development: A Systematic Review', Early Childhood Research Quarterly, 37 (2016), 39-57.

${ }^{6}$ Klingner Janette K, Teachng Reading Comprehension to Students with Learning Difficulties, 2/E (Guilford, 2015).

7 Keith Rayner and others, Psychology of Reading (Psychology Press, 2012).

8 Panayiota Kendeou, Kristen L McMaster, and Theodore J Christ, 'Reading Comprehension: Core Components and Processes', Policy Insights from the Behavioral and Brain Sciences, 3.1 (2016), 62-69. implemented properly. Therefore, readers must have an adequate vocabulary. Reading skill is necessary for the student not only to understand the information of the text but also the reader can apply it to life, such as education and work ${ }^{9}$.

Students' character education will also be stronger and firm by reading such kind of reading material, such as local cultural wisdom texts which contained valuable information ${ }^{10}$. Information in the reading text is also very important for social life in society. Reading can help people to understand the internet, email, letters, texts, and social media ${ }^{11} 12$ Therefore, reading comprehension is important to help readers to have good skills in written language.

Furthermore, motivating pupils and implementing a proper learning strategy may also help them to develop reading behavior and skills. One of the main components which gets the unique concentration in reading is motivation. Motivation is one of the significant components which is the way extraordinarily on achieving reading comprehension ${ }^{13} 1415$. The fact indicates

9 Jane Oakhill, Understanding and Teacbing Reading Comprehension 1st Edition (London and new york: Roudledge, 2015).

${ }^{10}$ Febria Sri Artika, 'Integrating The Character Education in Local Cultural Wisdom: A Concept in Developing A 2013 English Curriculum in Local Literary Works', Scientific Journal of PPI-UKM, 2.4 (2015), p.152-58.

${ }^{11}$ John Fiske, Reading the Popular (Routledge, 2017).

${ }_{12}$ Naomi S Baron, 'Reading in a Digital Age', Phi Delta Kappan, 99.2 (2017), 15-20.

13 Mohammad Reza Ahmadi, 'The Impact of Motivation on Reading Comprhension', International Journal of Research in English Education, 2017 $<$ https://doi.org/10.18869/acadpub.ijree.2.1.1>.

${ }^{14}$ Kelly B Cartwright, Timothy R Marshall, and Erica Wray, 'A Longitudinal Study of the Role of Reading Motivation in Primary Students' Reading Comprehension: Implications for a Less Simple View of Reading', Reading Psychology, 37.1 (2016), 55-91.

15 Sarah Logan, Emma Medford, and Naomi Hughes, 'The Importance of Intrinsic Motivation for High and Low Ability Readers' Reading Comprehension Performance', Learning and Individual Differences, 21.1 (2011), 124-28. 
motivation had a significantly constructive outcome on the reading comprehension process. Therefore, the teacher should be able to engage the students' reading interest to improve their reading comprehension ${ }^{161718}$ and reading strategy has a vital role within this situation. A creative teacher ought to have a strategy in teaching reading.

The $3 \mathrm{H}$ (Here, Hidden and in my Head) is one of the strategies that could improve students' reading comprehension. First, " $\mathrm{H}$ " is Here; this is utilized to discover the appropriate responses that are expressed in the content. It is here in one sentence, picture, title, inscription, realistic, and so on of the content. Students ought to have the option to place the appropriate response. The second " $\mathrm{H}$ " is Hidden; this $\mathrm{H}$ is utilized to discover the appropriate responses that are suggested in the content. It is found by consolidating data from at least two spots in the content, or by joining data from the content with what the understudy knows. The last " $\mathrm{H}$ " is Head; this $\mathrm{H}$-word is utilized to propose the appropriate response from the students ${ }^{\text {ee }}$ foundation information, from what they should identify ideas which aren't expressed in the content

There are three significant highlights of the $3 \mathrm{H}$ procedure: (a) it utilizes from the words Here, Hidden, and in My Head to show students' question and answer connections that are text express, text verifiable, and content certain, so this is anything but difficult to recall; (b) Showing teaching reading comprehension by Utilizing $3 \mathrm{H}$ is expected to actuate students' experience information which is essential to address questions; (c) it

16 Wahyuni Fitria, 'Reading Interest and Reading Comprehension: A Correlational Study', Journal Educative: Journal of Educational Studies, 4.1 (2019), p.95107.

${ }^{17}$ Abbas Pourhosein Gilakjani and Narjes Banou Sabouri, 'A Study of Factors Affecting EFL Learners' Reading Comprehension Skill and the Strategies for Improvement', International Journal of English Linguistics, 6.5 (2016), 180-87.

${ }^{18}$ Pourhosein Gilakjani and Sabouri. stresses the proper utilization of text data by urging students to rehash the entry specifically and to coordinate data from the content with their experience information. ${ }^{19}$

The $3 \mathrm{H}$ strategy is essential for developing and improving pupils' ability to read a text and make it better ${ }^{20}$. This strategy is good to be applied to explicit and implicit texts that students have different reading comprehension skill. The process of implementing the $3 \mathrm{H}$ strategy give a positive effect on students' comprehension.

There are several steps in implementing the $3 \mathrm{H}$ strategy. First lesson: (1) the teacher explains the $3 \mathrm{H}$ strategy to students so that they know the purpose of the strategy; the students ask questions to the teacher in three learning conditions: before, whilst, and after reading the text; (2) the teacher reads the text for students in front of the class. Students listen and follow the teacher's reading. Next, students mark the words they do not understand by underlining them. (3) the students note down the questions the student wants to ask at the bottom of the text. (4) The teacher distributes these questions to students. (5) The teacher then begins to train students about the process of the $3 \mathrm{H}$ strategy by asking students to discuss how to identify 3 questions based on the location of the answer. The teacher can exemplify the use of selfquestioning which serves to guide students in using the $3 \mathrm{H}$ strategy. (6) The teacher gives practice to students by asking students to label the questions written there 21 .

19 Lorraine Joy Graham, 'The 3H Strategy: Improving the Comprehension of Learning Disabled and Poor Readers through a Question-Answering Strategy' (Faculty of Education, 1992).

20 Cut sarah Maqfirah, 'Teaching Reading Comprehension by Using $3 \mathrm{H}$ (Here, Hidden, Head) Strategy', English Education Journal, 8 (2017a), p.338-51.

21 Nina Anggreni, Bambang Wijaya, and Syarif Husin, 'Teaching Reading Comprhension By Using $3 \mathrm{H}$ (Here, Hidden, and in My Head) Strategy', Jurnal Pendidikan Dan Pembelajaran, 3.7 (2014), p.1-14. 
Next lesson: explaining the procedures of $3 \mathrm{H}$. First, the teacher teaches students about the $3 \mathrm{H}$ strategy process in stages from the lowest to the higher level. The process is the basic level, the level of self-correction, and the level of reading back to the stage of understanding to ask and answer the reading text.

Second, the teacher teaches students about the mnemonic clue (Here). Furthermore, the teacher guides the class to the practice of the first mnemonic instructions. Fourth, the teacher tells students about hidden mnemonic practices as in the previous mnemonic clue steps. Fifth, teachers teach about the $3 \mathrm{H}$ strategy (in my head) in the same way ${ }^{22}$.

Next, to make it short, it can be stated about $3 \mathrm{H}$. First, the teacher demonstrates and tries hard to implement the first step of $3 \mathrm{H}$ (Here). Second, students try to apply these steps with the help of feedback from the teacher. Third, the teacher re-demonstrates the second step of the $3 \mathrm{H}$ (Hidden). Fourth, students apply the method in steps 1 and 2 with the help and guidance from the teacher. The teacher provides feedback to students as a form of improvement. Fifth, the teacher demonstrates the next $3 \mathrm{H}$ step (Head). Sixth, teachers practice strategies 1,2 , and 3 with the teacher's assistance and guidance. The teacher also always provides feedback to students as a form of evaluation. Finally, the teacher gives instructions and cues at the beginning of the stage slowly so that students are confident and can control these strategies ${ }^{23}$.

To increase students' understanding skills, the teacher can provide other activities that assist pupils in getting comfortable and excited about reading. This strategy can be

\footnotetext{
${ }^{22}$ NSW Department of Education, Programming and Strategies Handbook (Berkely Press, 1998).

${ }_{23}$ Peter Westwood, Reading and Learning Difficulties: Approaches to Teaching and Assessment (ACER Press, 2016).
}

used in descriptive text to describe certain objects, such as places, humans, animals, plants, and objects. That kind of text consists of two structures, namely identification, and description. The linguistic characteristics of descriptive text are using a special object, written in the present tense, using linking verbs, adjectives, and relational and material processes $^{24}$.

To assist pupils to develop their critical thinking, a teacher may determine to harness a more complect English text during the implementation of the $3 \mathrm{H}$ strategy in the text. This $3 \mathrm{H}$ strategy is expected to be a solution so that students' understanding of descriptive text becomes better and has high value.

\section{Method}

This research used quasi-experimental. Quasi-experimental design cannot manage all invalid sources from both outside and inside ${ }^{25}$. It differs from other designs in the absence of a randomized design.

Two classes were assigned as experimental class and control class in this study. The experimental class implemented the $3 \mathrm{H}$ point strategy. Control class is a class where the $3 \mathrm{H}$ strategy is not implemented, that is, students learn to read aloud. The type of test that is applied is the pre and post-test or also known as the pretest and posttest. Both types of text are treated in different class groups (control and experiment).

A population is a large group of research subjects 26 . The chosen population in this research was the 90 students of the VIII grades in SMPN 2 Danau Kembar, Solok,

${ }^{24}$ Beverly Derewianka, Exploring How Texts Work: 2nd Edition, 2nd edn (Primary English Teaching Association Australia, 2020).

25 Kerry Tanner, 'Experimental Resaerch', in Research Method: Information, Systems, and Contexts: Second Edition, 2018 <https://doi.org/10.1016/B978-0-08102220-7.00014-5>.

26 Arikunto, Metodelogi Penelitian, Suatu Pengantar Pendidikan, Rineka Cipta, Jakarta, 2019. 
West Sumatera (Indonesia) who were distributed into 4 classes.

From the population, the sample of the research was chosen. The sample is representative of the population so that the entire population can describe through that sample. The research sample consisted of 2 classes, namely the experimental class and the control class. To determine the two classes, the researcher used the purposive sampling technique after knowing the classes' average score, mean score on the preliminary test. The sample selection technique used was the purposive sampling technique, which is a technique that selects samples based on specific criteria. In this study, the sample was chosen because the students in the class had the same knowledge and were also supervised by the same English teacher.

To determine the research sample, several steps were implemented. First, knowing the classes' average score on a preliminary test which was given by the researcher. Its' aim is to see the average value of the entire population. This technique is also useful for determining the number of classes.

After testing, the two classes that got almost the same score were the 2 classes designated as the sample, namely the experimental class and control class. The researchers chose VIIIA and VIIIB as samples because both classes have almost similar mean scores as experimental and control classes and there was a similar number of students in both classes.

At the next step, the experimental research was conducted by applying the $3 \mathrm{H}$ strategy, as follows: (1) Pre-teaching activities, the teacher introduced the skill that student should achieve after learning the lesson. Next, the teacher did brainstorming activities. (2) Whilst teaching: The teacher explained the descriptive text to students then gave some examples. Next teacher explained about $3 \mathrm{H}$ strategy, then the teacher and students read the text. Then, the teacher constructed three kinds of questions: a) Some questions are based on the actual text. It is on the lines. Ex: The whole text above tells us about? b) Some questions that need to be inferred from information in the text. It is between the lines. Ex: What is the main idea of the second paragraph? c) Some questions that require the interaction of previous knowledge (in my Head). It is beyond the lines. Ex: According to the text above, which is not true about Valvo?, After that, the teacher demonstrated the process of each step: a) the teacher demonstrated how to answer or give relevant information regarding the question of the text, (Here). It is reading on the lines. b) The teacher demonstrated Hidden step to predict a possible answer. It is reading between the lines. c) The teacher demonstrated the in my Head step. It is beyond the lines. d) The students answer questions based on text information. 3) Post Teaching Activity: a) The teacher asks questions b) Teacher gives feedback, c) Teacher gives reinforcement to the class, d) Teacher concludes the lesson together with the students.

The models of the test as the instrument of study are valid and reliable. Validity is how much test measures should gauge $^{27}$. To get validity in this test, the instrumentation should give a shot to a different class in population. In examining the effect of try out test, the researchers isolated the thing as a right or erroneous answer from the test. This study used content validity as one of the significant aspects of the test accomplishment. It implies that the test given by the researcher to the students depend on the syllabus.

Reliability is how much a test reliably quantifies whatever it is estimating ${ }^{28}$. To see

\footnotetext{
${ }^{27}$ Suharsimi Arikunto, 'Prosedur Penelitian', 2019.
}

${ }^{28}$ Suharsimi Arikunto. 
the reliability of the test in the research, the researchers estimated the reliability of the test.

\section{Finding and Discussion \\ Finding}

The researcher gave a pretest to both classes before doing treatment of the experimental class.

Table 1. The Data of Students' Pretest Score.

\begin{tabular}{ccccc}
\hline Class & (n) & $\bar{x}$ & $\mathbf{X}$ max & $\mathbf{X}$ min \\
\hline Experiment & 24 & 69,83 & 77 & 57 \\
\hline Control & 24 & 68,88 & 77 & 57 \\
\hline
\end{tabular}

The mean score of the pretest in the experiment class was 69,83 and in the control class was 68,88 . This score was the students' capacity in the test class before doing the treatment.

After giving the post-test, the researchers examined the mean score, standard deviation, and fluctuation of the information dependent on the consequence of the post-test. This is the information about the students' post-test scores.

Table 2. The Data of Students' Posttest Score on Reading Comprehension of Descriptive Text

\begin{tabular}{|c|c|c|c|c|c|c|c|}
\hline $\begin{array}{c}\text { Homoge } \\
\text { Neity } \\
\text { Testing }\end{array}$ & $\begin{array}{c}\text { Clas } \\
\text { s }\end{array}$ & (n) & $\mathbf{S}$ & $\mathbf{S}^{2}$ & $\begin{array}{l}\mathrm{F} \\
\mathrm{c}\end{array}$ & Ft & $\begin{array}{l}\text { Varia } \\
\text { nces }\end{array}$ \\
\hline \multirow{2}{*}{ Pre-test } & $\begin{array}{l}\text { Exp } \\
\text { erim } \\
\text { ent }\end{array}$ & 24 & $\begin{array}{l}5, \\
98\end{array}$ & $\begin{array}{l}35 \\
7 \\
6\end{array}$ & \multirow{2}{*}{$\begin{array}{l}1, \\
22\end{array}$} & \multirow{2}{*}{$\begin{array}{c}2,0 \\
4\end{array}$} & $\begin{array}{c}\text { Hom } \\
\text { o }\end{array}$ \\
\hline & $\begin{array}{l}\text { Con } \\
\text { trol }\end{array}$ & 24 & 41 & $\begin{array}{l}29 \\
, 2 \\
7\end{array}$ & & & $\begin{array}{c}\text { gen } \\
\text { eou } \\
\text { s }\end{array}$ \\
\hline
\end{tabular}

From the table above, it is clear that the experimental class average value is higher than the control class. This shows that the $3 \mathrm{H}$ strategy was quite successful in increasing the students' understanding of reading text compared to the experiment which only read aloud.

Furthermore, the researchers used the normality test, homogeneity, and hypothesis testing to see the results of the study.
The following are the normality test values for the pre and post-test in both classes.

Table 3. The Normality of Students' Reading Comprehension Test Score

\begin{tabular}{|c|c|c|c|c|c|c|}
\hline $\begin{array}{c}\text { Nor } \\
\text { mali } \\
\text { ty } \\
\text { Test } \\
\text { ing }\end{array}$ & $\begin{array}{c}\text { Clas } \\
\text { s }\end{array}$ & $\begin{array}{c}\text { Num } \\
\text { ber of } \\
\text { Stude } \\
\text { nts } \\
\text { (N) }\end{array}$ & $(\alpha)$ & $\begin{array}{l}\text { Critical } \\
\text { Value } \\
\text { of } \\
\text { Accou } \\
\text { nting } \\
\left(\mathrm{L}_{\mathrm{o}}\right)\end{array}$ & $\begin{array}{c}\text { Critical } \\
\text { Value } \\
\text { of } \\
\text { Accou } \\
\text { nting } \\
\left(L_{t}\right)\end{array}$ & $\begin{array}{l}\text { Dist } \\
\text { ri- } \\
\text { buti } \\
\text { on }\end{array}$ \\
\hline \multirow{2}{*}{$\begin{array}{l}\text { Pret } \\
\text { est }\end{array}$} & $\begin{array}{l}\text { Exp } \\
\text { erim } \\
\text { ent }\end{array}$ & 24 & & 0,122 & \multirow{4}{*}{0.190} & $\begin{array}{l}\text { Nor } \\
\text { mal }\end{array}$ \\
\hline & $\begin{array}{c}\text { Cont } \\
\text { rol }\end{array}$ & 24 & 0.0 & 0,140 & & $\begin{array}{l}\text { Nor } \\
\mathrm{mal}\end{array}$ \\
\hline \multirow{2}{*}{$\begin{array}{l}\text { Post } \\
\text {-test }\end{array}$} & $\begin{array}{l}\text { Exp } \\
\text { erim } \\
\text { ent }\end{array}$ & 24 & 5 & 0,132 & & $\begin{array}{l}\text { Nor } \\
\text { mal }\end{array}$ \\
\hline & $\begin{array}{c}\text { Cont } \\
\text { rol }\end{array}$ & 24 & & 0,166 & & $\begin{array}{l}\text { Nor } \\
\mathrm{mal}\end{array}$ \\
\hline
\end{tabular}

The table shows the normality of the experimental class in the pretest that calculated normal coefficient $\mathrm{LO}=0,122$ at the significances level $95 \%$ and the table normality coefficient $\mathrm{Lt}=0.190$. It means that Lo $\leq \mathrm{Lt}$. The data from the control class were $\mathrm{Lo}=$ 0,140 while $\mathrm{Lt}=0.190$.

The normality of the posttest shows that the result of the posttest that calculated normally with coefficient $\mathrm{Lo}=0,132$ at the significances level $95 \%$ and the table normality coefficient $\mathrm{Lt}=0.190$. It means that $\mathrm{Lo} \leq \mathrm{Lt}$. The data from the control class were $\mathrm{Lo}=$ 0,166 , while $\mathrm{Lt}=0.190$. It means that $\mathrm{Lo} \leq \mathrm{Lt}$. In other words, the data distribution of the experimental and control classes is normal.

Furthermore, the researchers also conducted a homogeneity test to view and analyze the varied data in the experimental and control classes. The following is the value of the homogeneity test.

Table 4. The Result of Homogeneity Testing Pre test

\begin{tabular}{ccccc}
\hline Class & $\mathbf{N}$ & $\bar{x}$ & $\mathbf{X}$ max & $\mathbf{X}$ min \\
\hline Experiment & 24 & 75,71 & 87 & 57 \\
\hline Control & 24 & 69,54 & 87 & 57 \\
\hline
\end{tabular}

From the table above, it is shown that $F_{\text {calculated }} \leq \mathrm{F}_{\text {table }}(1.22 \leq 1,98)$ which reveals that 
the variance of both classes in pretest was homogeneous.

Then the researchers compared the homogeneity with the experimental class.

Table 5. Result of Homogeneity Testing Experimental Class

\begin{tabular}{|c|c|c|c|c|c|c|}
\hline Class & $\begin{array}{c}\text { Homoge } \\
\text { neity } \\
\text { Testing }\end{array}$ & (n) & $\mathbf{S}$ & $F_{c}$ & $F_{t}$ & $\begin{array}{c}\text { Varian } \\
\text { ce }\end{array}$ \\
\hline \multirow{2}{*}{$\begin{array}{l}\text { Exper } \\
\text { iment }\end{array}$} & Pretest & 24 & 5,98 & \multirow[b]{2}{*}{0,50} & \multirow{2}{*}{$\begin{array}{l}2, \\
04\end{array}$} & $\begin{array}{l}\text { Homog } \\
\text { eneous }\end{array}$ \\
\hline & Post-test & 24 & 8,38 & & & $\begin{array}{l}\text { Homog } \\
\text { eneous }\end{array}$ \\
\hline
\end{tabular}

The table above shows that $\mathrm{F}_{\text {calculated }} \leq \mathrm{F}_{\text {table }}(0,50 \leq 1,98)$, which means that the variance of both classes in the pre-test is homogeneous.

In the following table, the researchers show the result of homogeneity testing of the control class.

Table 6. Result of Homogeneity Testing Control Class

\begin{tabular}{ccccccc}
\hline Class & $\begin{array}{c}\text { Homoge } \\
\text { neity } \\
\text { Testing }\end{array}$ & (n) & $\mathbf{S}^{2}$ & $\mathbf{F}_{\mathbf{c}}$ & $\mathbf{F}_{\mathbf{t}}$ & $\begin{array}{c}\text { Varianc } \\
\mathbf{n}\end{array}$ \\
$\begin{array}{ccccc}\text { Con } \\
\text { trol }\end{array}$ & Pre test & 24 & 5,41 & & & $\begin{array}{c}\text { Homoge } \\
\text { neous }\end{array}$ \\
\cline { 2 - 4 } & Post test & 24 & 6,22 & 0,76 & 2,04 & $\begin{array}{c}\text { Homoge } \\
\text { neous }\end{array}$ \\
\hline
\end{tabular}

From the table above, Fcalculated $\leq \mathrm{F}_{\text {table }}$ $(0,76 \leq 1,98)$, which shows that the variance of both classes in the pre-test was homogeneous.

Then, the researchers also reveal the result of homogeneity testing post-test:

Table 7. The Result of Homogeneity Testing Post-test

\begin{tabular}{|c|c|c|c|c|c|c|c|}
\hline $\begin{array}{l}\text { Homo } \\
\text { geneity } \\
\text { Testing }\end{array}$ & Class & (n) & $\mathbf{S}$ & $\mathbf{S}^{2}$ & Fc & $\mathrm{Ft}$ & $\begin{array}{c}\text { Varianc } \\
\text { es }\end{array}$ \\
\hline \multirow{4}{*}{$\begin{array}{c}\text { Post- } \\
\text { test }\end{array}$} & & 2 & 8,3 & 70,2 & \multirow{4}{*}{$\begin{array}{c}1,8 \\
2\end{array}$} & \multirow{4}{*}{2,04} & \multirow{4}{*}{$\begin{array}{c}\text { Homoge } \\
\text { neous }\end{array}$} \\
\hline & $\operatorname{Exp}$ & 4 & 8 & 2 & & & \\
\hline & \multirow{2}{*}{ Cont } & 2 & 6,2 & 38,6 & & & \\
\hline & & 4 & 2 & 7 & & & \\
\hline
\end{tabular}

The table has clearly shown that $\mathrm{F}_{\text {calculated }} \leq \mathrm{F}_{\text {table }}(1,82 \leq 1,98)$. It means that $\mathrm{F}_{\text {calculated }} \leq \mathrm{F}_{\text {table. }}$. So, the two types of classes are homogeneous.

At the following table, the researchers show the result of testing the hypothesis:
Table 8: Hypothesis Testing

\begin{tabular}{|c|c|c|c|c|c|c|c|}
\hline $\begin{array}{c}\text { Homog } \\
\text { eneity } \\
\text { Testing }\end{array}$ & Class & (n) & $\mathbf{S}$ & S2 & Fc & $\mathbf{F t}$ & $\begin{array}{c}\text { Vari } \\
\text { anc } \\
\text { es } \\
\end{array}$ \\
\hline \multirow{2}{*}{ Pre-test } & $\begin{array}{c}\text { Experi } \\
\text { ment }\end{array}$ & 24 & 5,98 & $\begin{array}{c}35,7 \\
6 \\
\end{array}$ & \multirow{2}{*}{$\begin{array}{c}1,2 \\
2\end{array}$} & \multirow{2}{*}{$\begin{array}{c}2,0 \\
4\end{array}$} & $\begin{array}{c}\mathrm{Ho} \\
\mathrm{mog}\end{array}$ \\
\hline & $\begin{array}{c}\text { Con } \\
\text { trol } \\
\end{array}$ & 24 & 5,41 & $\begin{array}{c}29,2 \\
7\end{array}$ & & & $\begin{array}{c}\text { eneo } \\
\text { us }\end{array}$ \\
\hline
\end{tabular}

A hypothesis is a temporary statement that the validity must be tested in the research. Hypothesis in the research are as follow:

$\mathrm{H}_{0:}$ There is no positive impact from the $3 \mathrm{H}$ strategy on the descriptive text reading skills of students in grade VIII SMPN 2 Danau Kembar.

Ha: There is a positive impact of The $3 \mathrm{H}$ strategy on the descriptive text reading skills of students in grade VIII SMPN 2 Danau Kembar.

To know the differences between students' reading comprehension in both experimental and control classes, the researchers did a T-test statistical analysis and analyzed the result of a pre-test. The researcher got the data $\mathrm{T}_{\text {calculated }}=0,58$ and $\mathrm{T}_{\text {table }}(0,95 ; 46)=1,68$. In conclusion, Ho was received, and $\mathrm{Ha}$ was rejected. It means the students' reading comprehension before treatment was no significant.

In the next table, the result of the ttest on the experimental class is shown.

Table 9. Result of t-test on Experiment Class

\begin{tabular}{|c|c|c|c|c|c|c|c|}
\hline Test & (n) & $\mathbf{S}^{2}$ & $\mathbf{S}$ & $(\alpha)$ & $\mathbf{T}_{\mathrm{c}}$ & $\mathbf{T}_{\mathrm{t}}$ & Reference \\
\hline $\begin{array}{l}\text { Pre } \\
\text { test }\end{array}$ & 24 & 35,76 & 5,98 & & & & $\begin{array}{l}\text { Ho was } \\
\text { rejected }\end{array}$ \\
\hline $\begin{array}{l}\text { Post } \\
\text { test }\end{array}$ & 24 & 68,39 & 8,38 & 0,05 & 2,81 & 1,68 & $\begin{array}{l}\text { and } \mathrm{Ha} \\
\text { was } \\
\text { received }\end{array}$ \\
\hline
\end{tabular}

The researcher got the data $\mathrm{T}_{\text {calculated }}=$ 2,96 and $\mathrm{T}_{\text {table }}(0,95 ; 46)=1,68$. Therefore, Ho was rejected and $\mathrm{Ha}$ accepted. In other words, the $3 \mathrm{H}$ strategy can improve students' understanding of understanding descriptive texts.

Then, in the following table, the result of the t-test on the control class can be seen. 
Table 10. Result of t-test on Control Class

\begin{tabular}{|c|c|c|c|c|c|c|c|}
\hline Test & (n) & $\mathbf{S}^{2}$ & $\mathbf{S}$ & $(\alpha)$ & $\mathbf{T}_{\mathrm{c}}$ & $\mathbf{T}_{\mathrm{t}}$ & Reference \\
\hline $\begin{array}{l}\text { Pre } \\
\text { test }\end{array}$ & 24 & 29,27 & 5,41 & \multirow{2}{*}{0,05} & \multirow[b]{2}{*}{1,97} & \multirow[b]{2}{*}{1,68} & $\begin{array}{l}\text { Ho was } \\
\text { rejected }\end{array}$ \\
\hline $\begin{array}{l}\text { Post } \\
\text { test }\end{array}$ & 24 & 38,69 & 6,22 & & & & $\begin{array}{l}\text { and } H \\
\text { was } \\
\text { received }\end{array}$ \\
\hline
\end{tabular}

The table shows that the researcher got the data $\mathrm{T}_{\text {calculated }}=1,97$ and $\mathrm{T}_{\text {table }}(0,95 ; 46)=$ 1,68. So, Ho was accepted and $\mathrm{Ha}$ was rejected. In other words, the result of increasing students' ability from the reading aloud strategy was not higher than the $3 \mathrm{H}$ strategy.

At this table, the researchers tried to reveal the t-test on post-test.

Table 11. Result of t-test on post-test

\begin{tabular}{|c|c|c|c|c|c|}
\hline Class & (n) & $\mathrm{S}^{2}$ & S & $(\alpha)$ & $\begin{array}{ll}\mathrm{T}_{\mathrm{c}} & \mathrm{T}_{\mathrm{t}}\end{array}$ \\
\hline Exp & 24 & 68,39 & 8,38 & \multirow{2}{*}{0,05} & \multirow{2}{*}{2,91} \\
\hline Cntrl & 24 & 38,69 & 6,22 & & \\
\hline
\end{tabular}

The table shows that the $\mathrm{T}_{\text {calculated }}=2,91$ and $\mathrm{T}_{\text {table }}(0,95 ; 46)=1,68$. This means that $\mathrm{Ho}$ is rejected and $\mathrm{Ha}$ is accepted. So, the $3 \mathrm{H}$ strategy is considered more successful in improving student understanding than the Reading Aloud Strategy.

The comparison of experiment and control class pre-test and post-test could be seen in the following table.

Table 12. Experiment and control class pre-test and post-test

\begin{tabular}{|c|c|c|c|c|c|c|c|}
\hline Class & (n) & $\mathbf{S}^{2}$ & S & A & $\mathbf{T}_{\mathrm{c}}$ & $T_{t}$ & $\begin{array}{c}\text { Referen } \\
\text { ce }\end{array}$ \\
\hline Exp & 24 & $\begin{array}{l}35 \\
76\end{array}$ & 5,98 & \multirow[b]{2}{*}{0,05} & \multirow{2}{*}{$\begin{array}{c}0,5 \\
7\end{array}$} & \multirow{2}{*}{$\begin{array}{c}1,6 \\
8\end{array}$} & $\begin{array}{l}\text { Ho was } \\
\text { received }\end{array}$ \\
\hline Cntrl & 24 & $\begin{array}{l}29 \\
27\end{array}$ & 5,41 & & & & $\begin{array}{l}\text { and } \mathrm{Ha} \\
\text { was } \\
\text { rejected }\end{array}$ \\
\hline
\end{tabular}

Based on the findings, the researchers recommend the use of the $3 \mathrm{H}$ strategy to improve students' reading comprehension.

\section{Discussion}

The results indicate the success of the implementation $3 \mathrm{H}$ ( Head, Hidden, and My Head ) strategy in overcoming problems regarding pupils' reading ability. This is indicated by three important findings, as follows.

The most important first finding result is obtained from the average score of students' ability through the $3 \mathrm{H}$ strategy in the experimental class. It appears that the students 'scores increased after the $3 \mathrm{H}$ strategy was implemented compared to the students' scores before the $3 \mathrm{H}$ strategy, namely 69.83 to 75.71 .

The second research finding was obtained from the mean score of students after implementing the reading aloud strategy in the control class. The students' scores in the control class only increased slightly after the implementation of the reading aloud strategy, from 68.88 to 69.54 which means the increase is only 1.34 from that strategy.

The third research result is a comparison of the students 'scores after implementing the 3H strategy with the students' scores after implementing the reading aloud strategy.

Based on the comparison of the mean scores, it appears that the mean score of the students after implementing the $3 \mathrm{H}$ strategy was much higher than $t$ reading aloud strategy's score. Or in other words, the students' score in the experimental class is better than control class. So, the $3 \mathrm{H}$ strategy had more effect on the students' ability to read descriptive text compared to the reading aloud strategy; the mean score in the control class was only 1.34 while in the experimental class was 5.88 . The $3 \mathrm{H}$ strategy has a large effect as much as 4.54 points higher than the reading aloud strategy which means that the use of the $3 \mathrm{H}$ strategy is effective to improve students' reading comprehension compared to the readaloud strategy. 
The usage of the $3 \mathrm{H}$ strategy in experimental class shows that students have an enthusiasm for learning. The students demonstrated focus when they were taught through the $3 \mathrm{H}$ Strategy. The students were prepared to discover the appropriate response "Here" step, it is on the lines, the students were prepared to practice to discover the appropriate response "Hidden" step, it is between the lines, the students' were prepared to practice to discover "in my Head" step, it is past lines.

The $3 \mathrm{H}$ strategy has also helped the students to foresee the content of the text before they read the text and get the data from the text whether it is unequivocal, verifiable, and the data that as of now in the students' background knowledge. ${ }^{29}$

Besides, the research has also proved that the $3 \mathrm{H}$ strategy is a strategy that enables to show youngsters, where to, responds to the inquiries. An answer is either unequivocally, inferred in the content and can consolidate it with earlier information (Hidden) ${ }^{30}$

The finding of the current study is also similar to the findings of several researchers in a language classroom. Experimental research on teaching reading narrative text using Combining Picture Walk and 3H Strategies has shown better students' reading comprehension scores. The students' motivation in learning by using this strategy has affected their learning outcomes ${ }^{31}$.

Another researcher also conducted experimental research by combining The $3 \mathrm{H}$ and QTA (Questioning The Author) Strategy for Junior High School in teaching reading. This study points to the fact that these strategies can improve students' ability to

${ }^{29}$ Graham.

${ }^{30}$ Westwood.

31 Suharni, 'Teaching Reading Narrative Text Through Combining Picture Walk and Here Hidden in My Head $(3 \mathrm{H})$ Strategies at Eight Grade Students of Junior High School', Jurnal Mahasiswa Bahasa Inggris Genap 2012-2013, Vol 2, No (2013). understand the content of the text. The students can identify what information is contained in the text ${ }^{32}$.

In line with the research, another study also reports that the $3 \mathrm{H}$ strategy can increase students' outcomes in reading texts, especially narrative texts. This experimental research used $3 \mathrm{H}$ strategy in the experimental class and the grammar-translation method in the control class $^{33}$.

Another study that also agrees with this $3 \mathrm{H}$ strategy assistance is a study conducted at the Tapung Kampar 1 Senior High School which states that the $3 \mathrm{H}$ strategy can also improve students' scores in reading text ${ }^{34}$. This understanding is experimental to distinguish it from the control class. In addition to increasing students' scores in understanding the $3 \mathrm{H}$ strategy, it also enables students to think skillfully and strategically so that students can absorb various sources of information through individual understanding questions ${ }^{35}$.

The $3 \mathrm{H}$ strategy turned out to also enable students to answer all text comprehension questions and be skilled in

32 Syefriyanti, 'Teaching Reading In Narrative Text By Combining The $3 \mathrm{H}$ and Qta (Questioning The Author) Stratgy For Junior High School', Pendidikan Bahasa Inggris, 2013.

${ }^{33}$ Resti Riyani, 'Teaching Narrative Reading Text by Using $3 \mathrm{H}$ Strategy to the Tenth Grade Students of Senoir High School of Arinda Palembang, Edukasi: Jurnal Pendidikan Dan Pengajaran, 2016.

${ }^{34}$ Novianti Sri Rejeki, 'The Effect of Using Here, Hidden, and in My Head (3H) Strategy towards Reading Comprehension in Narrativ Text of the First Year Students at SMAN 1 Tapung of Kampar Regency', 2013.

35 Sa'adatul Hayati, 'The Effectiveness of Using $3 \mathrm{H}$ (Here, Hidden, and in My Head) Strategy toward Students' Reading Comprehension Mastery at the Second Grade of SMKN 1 Boyolangu', BMC Public Health (State Islamic Institute (IAIN) Of Tulungagung, 2017)<https:/ / ejournal.poltektegal.ac.id/index.php/sikl us/article/view/298\%0Ahttp://repositorio.unan.edu.ni /2986/1/5624.pdf\%0Ahttp://dx.doi.org/10.1016/j.jan a.2015.10.005\%0Ahttp:/ /www.biomedcentral.com/147 1 -

2458/12/58\%0Ahttp://ovidsp.ovid.com/ovidweb.cgi? $\mathrm{T}=\mathrm{JS} \& \mathrm{P}>$. 
making reading conclusions. ${ }^{36}$ The conclusion of this study was obtained from a study that combined $3 \mathrm{H}$ with the click and clank strategy. The results showed that the combination of the 2 strategies made the students' reading comprehension higher. The constraint of this research is that the type of text has not been determined to test the combination of the two strategies. This research was only conducted with a general system and incomplete processes ${ }^{37}$. Therefore, it clears that these studies have strengthened the current finding that the $3 \mathrm{H}$ strategy gives positive effect on students' reading skill.

\section{Conclusion}

In the light of the consequences of the research, the $3 \mathrm{H}$ strategy provides a constructive result on students' reading comprehension of the descriptive text. Using $3 \mathrm{H}$ further increases students' motivation and enthusiasm during the teaching process and can create a good learning environment that is both brilliant and fun.

It is proposed that English teachers use this strategy in teaching reading, and the researchers recommend other scholars are researching this strategy with a different distinctive types of text. At that point, further, the studies can likewise explore the adequacy of the $3 \mathrm{H}$ strategy with students at different levels just as for other English skills to enhance information about the usage of teaching strategies. At that point, the studies can also explore the adequacy of the $3 \mathrm{H}$ strategy with students at different levels, as well as with other English skills, in order to improve information on the use of teaching strategies.

${ }^{36}$ Devi Selvia, The Use of the $3 \mathrm{H}$ (Here, Hidden, in My Head) Strategy in Teaching Reading Comprehension to English Department Students, 2016.

${ }^{37}$ Nur Anisa, 'Teaching Reading by Combining Click and Clunk and 3H Strategy at Snior High School' (State University of Padang).

\section{References}

\section{Book}

Hayati, Sa'adatul, 'The Effectiveness of Using $3 H$ (Here, Hidden, and in My Head) Strategy toward Students' Reading Comprehension Mastery at the Second Grade of SMKN 1 Boyolangu', BMC Public Health (State Islamic Institute (IAIN) Of Tulungagung, 2017)

Novianti Sri Rejeki, 'The Effect of Using Here, Hidden, and in My Head (3H) Strategy towards Reading Comprehension in Narrative Text of the First Year Students at SMAN 1 Tapung of Kampar Regency', 2013

Nur Anisa, 'Teaching Reading by Combining Click and Clunk and $3 \mathrm{H}$ (Here, Hidden, in My Head) Strategy at Senior High Schoop (State University of Padang)

Derewianka, Beverly, Exploring How Texts Work: 2nd Edition, 2nd edn (Primary English Teaching Association Australia, 2020)

Devi Selvia, The Use of the 3 H (Here, Hidden, in My Head) Strategy in Teaching Reading Comprehension to English Department Students, 2016

NSW Department of Education, Programming and Strategies Handbook (Berkely Press, 1998)

Oakhill, Jane, Understanding and Teaching Reading Comprehension 1st Edition (London and new york: Roudledge, 2015)

Westwood, Peter, Reading and Learning Difficulties: Approaches to Teaching and Assessment (ACER Press, 2016)

Graham, Lorraine, 'The $3 H$ Strategy: Improving the Comprehension Learning Disabled and Poor Readers Through A Question-Answering Strategy', 1970

Arikunto, Metodelogi Penelitian, Suatu Pengantar Pendidikan, Rineka Cipta, Jakarta, 2019

Arikunto, Suharsimi, 'Prosedur Penelitian', 2019

Janette K, Klingner, Teaching Reading Comprehension to Students with Learning Difficulties, 2/E (Guilford, 2015) 


\section{Journal}

Ahmadi, Mohammad Reza, 'The Impact of Motivation on Reading Comprehension', International Journal of Research in English Education, 2017 $<$ https://doi.org/10.18869/acadpub.ijre e.2.1.1 $>$

Angreni, Nina, Bambang Wijaya, and Syarif Husin, 'Teaching Reading Comprehension By Using 3H (Here, Hidden, and in My Head) Strategy', Jurnal Pendidikan Dan Pembelajaran, 3.7 (2014), 1-14

Artika, Febria Sri, 'Integrating The Character Education in Local Cultural Wisdom: A Concept in Developing A 2013 English Curriculum in Local Literary Works', Scientific Journal of PPI-UKM, 2.4 (2015), 152-58

Baron, Naomi S, 'Reading in a Digital Age', Janette K, Klingner, Teaching Reading Phi Delta Kappan, 99.2 (2017), 15-20

Cartwright, Kelly B, Timothy R Marshall, and Erica Wray, 'A Longitudinal Study of the Role of Reading Motivation in Primary Students' Reading Comprehension: Implications for a Less Simple View of Reading', Reading Psychology, 37.1 (2016), 55-91

Collingwood, David, 'Understanding and Teaching Reading Comprehension. A Handbook', Educational Psychology in Practice, 2015 $<$ https://doi.org/10.1080/02667363.201 $5.1052233>$

Derewianka, Beverly, Exploring How Texts Work: 2nd Edition, 2nd edn (Primary English Teaching Association Australia, 2020)

Devi Selvia, The Use of the 3 H Here, Hidden, in My Head) Strategy in Teaching Reading Comprehension to English Department Students, 2016

Fiske, John, Reading the Popular (Routledge, 2017)

Fitria, Wahyuni, 'Reading Interest and Reading Comprehension: A Correlational Study', Journal Educative: Journal of Educational
Studies, 4.1 (2019), 95-107

Gilakjani, Abbas Pourhosein, and Narjes Banou Sabouri, 'A Study of Factors Affecting EFL Learners' Reading Comprehension Skill and the Strategies for Improvement', International Journal of English Linguistics, 6.5 (2016), 180-87

Graham, Lorraine Joy, 'The $3 \mathrm{H}$ Strategy: Improving the Comprehension of Learning Disabled and Poor Readers through a Question-Answering Strategy' (Faculty of Education, 1992)

Hayati, Sa'adatul, 'The Effectiveness of Using $3 \mathrm{H}$ (Here, Hidden, and in My Head) Strategy toward Students' Reading Comprehension Mastery at the Second Grade of SMKN 1 Boyolangu', BMC Public Health (State Islamic Institute (IAIN) Of Tulungagung, 2017) Comprehension to Students with Learning Difficulties, 2/E (Guilford, 2015)

Kendeou, Panayiota, Kristen L McMaster, and Theodore J Christ, 'Reading Comprehension: Core Components and Processes', Policy Insights from the Behavioral and Brain Sciences, 3.1 (2016), 62-69

Krashen, Stephen, 'Reading and Vocabulary Acquisition: Supporting Evidence and Some Objections.', Iranian Journal of Language Teaching Research, 1.1 (2013), 2743

Logan, Sarah, Emma Medford, and Naomi Hughes, The Importance of Intrinsic Motivation for High and Low Ability Readers' Reading Comprehension Performance', Learning and Individual Differences, 21.1 (2011), 124-28

Maqfirah, cut sarah, 'Teaching Reading Comprehension by Using $3 \mathrm{H}$ (Here, Hidden, Head) Strategy', English Education Journal, 8 (2017), 338-51

Novianti Sri Rejeki, 'The Effect of Using Here, Hidden, and in My Head $(3 \mathrm{H})$ Strategy towards Reading Comprehension in Narrative Text of the First Year Students at SMAN 1 Tapung 
of Kampar Regency', 2013

Nur Anisa, 'Teaching Reading by Combining Click and Clunk and $3 \mathrm{H}$ (Here, Hidden, in My Head) Strategy at Senior High School' (State University of Padang)

Pourhosein Gilakjani, Abbas, and Narjes Banou Sabouri, 'How Can Students Improve Their Reading Comprehension Skill?', Journal of Studies in Education, 6.2 (2016), 229 <https://doi.org/10.5296/jse.v6i2.9201 $>$

Rayner, Keith, Alexander Pollatsek, Jane Ashby, and Charles Clifton Jr, Psychology of Reading (Psychology Press, 2012)

Riyani, Resti, 'Teaching Narrative Reading Text by Using $3 \mathrm{H}$ (Here, Hidden, in My Haed) Strategy to the Tenth Grade Students of Senior High School of Arinda Palembang', Edukasi: Jurnal Pendidikan Dan Pengajaran, 2016

Suharni, 'Teaching Reading Narrative Text Through Combining Picture Walk and
Here Hidden in My Head (3H) Strategies at Eight Grade Students of Junior High School', Jurnal Mahasiswa Bahasa Inggris Genap 2012-2013, Vol 2, No (2013)

Suk, Namhee, 'The Effects of Extensive Reading on Reading Comprehension, Reading Rate, and Vocabulary Acquisition', Reading Research Quarterly, 52.1 (2017), 73-89

Syefriyanti, 'Teaching Reading In Narrative Text By Combining The $3 \mathrm{~h}$ (Here, Hidden In My Head) And Qta (Questioning The Author) Strategy For Junior High School', Pendidikan Bahasa Inggris, 2013

Tanner, Kerry, 'Experimental Research', in Research Methods: Information, Systems, and Contexts: $\quad$ Second Edition, 2018 $<$ https://doi.org/10.1016/B978-0-08102220-7.00014-5>

Wasik, Barbara A, Annemarie H Hindman, and Emily K Snell, 'Book Reading and Vocabulary Development: A Systematic Review', Early Childhood Research Quarterly, 37 (2016), 39-57 